International Journal of Current Microbiology and Applied Sciences

ISSN: 2319-7706 Volume 10 Number 02 (2021)

Journal homepage: http://www.ijcmas.com

\title{
Effect of Bio-Regulator Treatment, Wounding and Growing Media on Root Growth of Stem Cutting in Lemon (Citrus limon Burm.)
}

\author{
Babloo Patel $^{1 *}$, Satya Prakash ${ }^{1}$, Archi Gupta ${ }^{1}$, Shardulya Shukla ${ }^{2}$, \\ Pushkar Dixit ${ }^{3}$, Sonu Katiyar ${ }^{4}$ and Kaushlendra Pratap Singh ${ }^{1}$ \\ ${ }^{1}$ Department of Horticulture, Sardar Vallabhbhai Patel University of Agriculture and \\ Technology, Meerut (U. P.), India \\ ${ }^{2}$ Defence Institute of High Altitude Research, DRDO, Leh Ladakh, India \\ ${ }^{3}$ Vishweswaraya institute of Engineering and Technology Dadri, Greater Noida, U.P., India \\ ${ }^{4}$ Department of Plant Pathology, Sardar Vallabhbhai Patel University of Agriculture and \\ Technology, Meerut (U. P.), India \\ *Corresponding author
}

Keywords

Tarai, Rutaceae, root length, length of longest root, root thickness

Article Info

Accepted:

20 January 2021

Available Online:

10 February 2021
The present investigation was conducted during 2017-18 at Horticultural Research Centre of Sardar Vallabhbhai Patel University of Agriculture and Technology, Meerut (UP) - 250110. The experiment was laid out in Factorial RBD with 4 replications in each treatment. Total eight treatments including control i.e., Control (stem cuttings without wounding and without bio-regulator treatments) T1, Stem cuttings with wounding (T2), Stem cuttings +2000 ppm IBA (T3), Stem cuttings +4000 ppm IBA (T4), Stem cuttings +6000 ppm IBA (T5), Stem cuttings with wounding +2000 ppm IBA(T6), Stem cuttings with wounding +4000 ppm IBA(T7) and Stem cuttings with wounding +6000 ppm IBA (T8). Out of these, the treatment 4000 ppm IBA + wounding significantly increased the maximum root growth of stem cuttings in terms of number of root, root length, length of longest root, root thickness and root dry weight of lemon (Citrus limon Burm).

\section{Introduction}

Lemon (Citrus limon L.) is an important plant of Citrus species belongs to the family Rutaceae. It comes under the category of acid fruits and used for culinary and nonculinary purposes throughout the world. Lemon is an important fruit crop of Tarai, and western plain zone of Uttar Pradesh and valley areas of hill region as well. Lemon has potential to 
bear in many flushes making it long lasting crop having round the year availability of the fruits and longer shelf-life. It has gained more importance as kitchen garden fruit. Lemon is used for the preparation of lemonade, refreshing drinks and for a wide variety of culinary preparations like pies, cakes, dishes of vegetables, fish, meat and salad. It is extensively used with tea in Russia. The lemon oil is a stimulant and carminative when given internally as medicine. Lemon juice along with common salt is recommended as a remedy for dysentery, dry bleach, putrid, sore throat and for correcting foetid breath. Lemon juice is widely used in the preparation of soft drinks and possesses special dietic and medicinal values, associated with its high vitamin $\mathrm{C}$ content.

Lemon is usually propagated by seeds which are commonly polyembryonic in nature, resulting heterogeneous population and high chance of viral disease contamination by this method (Babu, 2001). Rooting of the cutting is one of the possible techniques for vegetative propagation and it was observed that cuttings play important roles in the rooting of important species of some fruit species and colonal rootstocks. Cutting is considered an alternative technique, providing genetic purity and uniformity in planting material, especially as plants with limited seed availability, such as low seed producing cultivars, and recalcitrant nature of seed. Furthermore, propagation through stem cuttings is inexpensive, rapid and simple technique as compared to other vegetative methods. Use of plant growth regulators and chemicals is a boon to horticulture and is being used for various purposes with an ultimate aim to increase production. The auxin indole- butyric acid has been identified as rooting hormones. Exogenous application of IBA induces rooting of stem cuttings. It promotes rooting as well as number of roots. The stimulation of adventitious root formation in stem cuttings treated with auxin is well known (Blazich, 1988).

\section{Materials and Methods}

The present study was carried out at Sardar Vallabhbhai Patel University of Agriculture and Technology, Meerut, 250110 (UP), during 2017-18 to Study the Effect of bioregulator treatment, wounding and growing media on root growth of stem cutting in lemon (Citrus limon Burm.). The experiment was laid out in Factorial RBD with 4 replications in each treatment. There were 8 treatments with 2 stem cuttings in each replication of all 16-treatment combinations. Total eight treatments including control i.e., Control (stem cuttings without wounding and without bioregulator treatments) T1, Stem cuttings with wounding (T2), Stem cuttings +2000 ppm IBA (T3), Stem cuttings + 4000 ppm IBA(T4), Stem cuttings + 6000 ppm IBA(T5), Stem cuttings with wounding $+2000 \mathrm{ppm}$ IBA(T6), Stem cuttings with wounding + 4000 ppm IBA(T7) and Stem cuttings with wounding +6000 ppm IBA(T8). For obtaining stem cuttings, 9-10month old shoots of Pant Lemon-1 cultivar of lemon was selected for conducting experiment. Two rooting media were prepared and filled in polybags. About 1$1.5 \mathrm{~kg}$ growing medium was filled in each polybag. The details of growing media used for the study are as follows: soil + sawdust + vermi-compost @ 1:1:1 and soil + sawdust + FYM @ 1:1:1. The propagation study was carried out under net house in which there was a provision of 50 percent shade. The stock solution of 12000 ppm IBA (Indole Butyric Acid) was prepared as per the procedure described by Prakash (1984). The $18 \mathrm{~cm}$ long and pencil thickness sized cuttings were made and treated with prepared IBA solution according to different doses of IBA. Thereafter, cuttings were planted in poly-bags and placed in shade net-house during third week of July month. The various observations 
like Number of roots per cutting, Root length of cutting, Length of longest root, Root thickness of stem cutting and Dry weight of root were recorded. The recorded data were statistically analyzed by using Factorial RBD as suggested by Panse and Sukhatme (1985).

\section{Results and Discussion}

The data presented in Table 1 indicated that application of 4000 ppm IBA + wounding significantly increased the maximum root growth of stem cuttings in terms of number of root, root length, length of longest root, root thickness and root dry weight. When IBA and wounding treated cuttings planted in vermicompost containing rooting medium, the root growth was found to be significantly better than root growth of those treated cuttings grown in FYM containing rooting medium. Significant increase in root growth of stem cutting in terms of number of root when treated with moderate concentration of IBA and planted in vermicompost containing rooting medium as reported in the present study has also been reported by Singh and Singh., (2005), Kumar et al., (1995) and Kato., (1958). Significantly longer root in stem cuttings as recorded in the present study when treated with IBA treatments was also observed by Ghatnatti., (1997), Singh et al., (2002), and Abdullah and Al-khateeb., (2004).

The possible reason for significant increase in root length of IBA and wounded treated cuttings may be due to the action of auxins in terms of hydrolysis and translocation of carbohydrate and nitrogen substances at the base of cutting which resulted in accelerating cell elongation and cell division in suitable environment (Singh et al., (2003). The length of longest root in IBA + wounding treated stem cutting was also found to be significantly higher when grown in soil + sawdust + vermicompost rooting medium in the present study because of the fact that optimum dose of
IBA and vermicompost and sawdust containing rooting medium significantly favored elongation of root due to the assimilation and translocation of auxins compound in rooted cuttings (Sharma et al., (2009), Murkute et al., (2009) and Verma et al., (2005). Well drained rooting medium is also promoted the better development of roots by penetration of roots in the sawdust and vermicompost containing rooting medium. The findings of propagation studies carried out by Singh et al., (2002) also confirmed the findings of present investigation. Significant increase in root thickness of stem cuttings treated with IBA + wounding may be due to the fact that auxin plays an important role in the metabolic activities and cell division which resulted in increase of root growth (Deb et al., (2009).

Thus it may be concluded that increased in the size of roots judged in terms of length and diameter of treated cuttings in the present study was most probably due to early callus formation following IBA, wounding and vermicompost containing rooting medium treatment. The results obtained on significant improvement in root growth of IBA treated cuttings are also in accordance with the findings of Dhua and Sen, (1984), Sandhu and Singh, (1986) and Kumar et al., (2004). The better root growth of treated cuttings recorded in the present study may also be because of the fact that in early sprouted cutting due to greater nutrient uptake, the subsequent growth started early and therefore such cuttings grew more vigorously. As a result, the root growth of cutting might have increased. There was also significant improvement in number of roots, root length, length of longest root, root thickness and root dry weight when grown in vermicompost containing rooting medium. Good container media management is the basic for the production of quality container grown nursery plants (Kumar and Ponnuswami, 2013). 
Table.1 Effect of different doses of IBA and rooting media on root parameters of stem cutting in Lemon

\begin{tabular}{|c|c|c|c|c|c|c|c|c|c|c|c|c|c|c|c|}
\hline \multirow[b]{3}{*}{ Treatments } & \multirow{2}{*}{\multicolumn{3}{|c|}{ Number of roots }} & \multirow{2}{*}{\multicolumn{3}{|c|}{ Root length of stem }} & \multirow{2}{*}{\multicolumn{3}{|c|}{ Length of longest root $(\mathrm{cm})$}} & \multirow{2}{*}{\multicolumn{3}{|c|}{ Root thickness (mm) }} & \multicolumn{3}{|c|}{$\begin{array}{c}\text { Dry weight of root } \\
\text { (gm) }\end{array}$} \\
\hline & & & & & & & & & & & & & Roc & ting me & \\
\hline & $\begin{array}{c}\text { Soil + } \\
\text { sawdust + } \\
\text { vermi- } \\
\text { compost }\end{array}$ & $\begin{array}{l}\text { Soil + } \\
\text { sawdust + } \\
\text { FYM }\end{array}$ & Mean & $\begin{array}{c}\text { Soil + } \\
\text { sawdust } \\
+ \\
\text { vermi- } \\
\text { compost }\end{array}$ & $\begin{array}{c}\text { Soil + } \\
\text { sawdust } \\
\text { + FYM }\end{array}$ & Mean & $\begin{array}{c}\text { Soil + } \\
\text { sawdust } \\
+ \text { vermi- } \\
\text { compost }\end{array}$ & $\begin{array}{c}\text { Soil }+ \\
\text { sawdus } \\
t+ \\
\text { FYM }\end{array}$ & Mean & $\begin{array}{c}\text { Soil + } \\
\text { sawdust } \\
+ \\
\text { vermi- } \\
\text { compost }\end{array}$ & $\begin{array}{c}\text { Soil }+ \\
\text { sawdus } \\
t+ \\
\text { FYM }\end{array}$ & Mean & $\begin{array}{c}\text { Soil + } \\
\text { sawdust } \\
+ \\
\text { vermi- } \\
\text { compost }\end{array}$ & $\begin{array}{l}\text { Soil + } \\
\text { sawd } \\
\text { ust }+ \\
\text { FYM }\end{array}$ & Mean \\
\hline T1 & 7.01 & 6.06 & 6.53 & 4.83 & 4.25 & 4.54 & 8.12 & 6.61 & 7.36 & 0.49 & 0.43 & 0.46 & 1.31 & 1.24 & 1.27 \\
\hline $\mathbf{T 2}$ & 8.24 & 6.98 & 7.61 & 5.14 & 4.71 & 4.92 & 8.44 & 7.59 & 8.01 & 0.56 & 0.51 & 0.53 & 1.45 & 1.32 & 1.38 \\
\hline T3 & 10.95 & 9.16 & 10.05 & 6.27 & 5.27 & 5.77 & 10.45 & 9.37 & 9.91 & 0.68 & 0.62 & 0.65 & 1.57 & 1.48 & 1.52 \\
\hline T4 & 13.54 & 12.09 & 12.81 & 8.40 & 7.39 & 7.89 & 13.20 & 12.00 & 12.60 & 0.82 & 0.69 & 0.75 & 1.82 & 1.76 & 1.79 \\
\hline T5 & 12.09 & 10.46 & 11.27 & 6.93 & 6.30 & 6.61 & 12.35 & 11.15 & 11.75 & 0.76 & 0.65 & 0.70 & 1.71 & 1.63 & 1.67 \\
\hline T6 & 15.03 & 14.24 & 14.63 & 9.04 & 8.13 & 8.58 & 13.96 & 12.68 & 13.32 & 0.87 & 0.76 & 0.81 & 1.91 & 1.85 & 1.88 \\
\hline T7 & 20.61 & 17.29 & 18.95 & 10.84 & 9.94 & 10.39 & 15.95 & 15.03 & 15.49 & 1.34 & 1.16 & 1.25 & 2.20 & 2.09 & 2.14 \\
\hline T8 & 17.88 & 15.09 & 16.48 & 9.92 & 8.96 & 9.44 & 14.90 & 13.67 & 14.28 & 0.99 & 0.87 & 0.93 & 2.06 & 1.96 & 2.01 \\
\hline $\begin{array}{l}\text { Overall } \\
\text { Mean }\end{array}$ & 13.17 & 11.42 & 12.29 & 7.67 & 6.87 & 7.27 & 12.17 & 11.01 & 11.59 & 0.81 & 0.71 & 0.76 & 1.75 & 1.66 & 1.70 \\
\hline \multicolumn{4}{|l|}{$\mathrm{CD}(\mathrm{P}=\mathbf{0 . 0 5})$} & \multicolumn{3}{|c|}{$\mathrm{CD}(\mathrm{P}=0.05)$} & \multicolumn{3}{|c|}{$\mathrm{CD}(\mathrm{P}=0.05)$} & \multicolumn{3}{|c|}{$\mathrm{CD}(\mathrm{P}=0.05)$} & \multicolumn{3}{|c|}{$\mathrm{CD}(\mathrm{P}=0.05)$} \\
\hline \multicolumn{3}{|c|}{ Chemical \& Mechanical treatments } & 0.81 & & & 1.07 & & & 0.70 & & & 0.11 & & & 0.02 \\
\hline \multicolumn{3}{|c|}{ Rooting media } & 0.40 & & & 0.53 & & & 0.35 & & & 0.06 & & & 0.04 \\
\hline \multicolumn{3}{|c|}{$\begin{array}{c}\text { Chemical \& Mechanical treatments } \times \\
\text { Rooting media }\end{array}$} & 1.15 & & & 1.52 & & & 0.99 & & & 0.16 & & & 0.05 \\
\hline
\end{tabular}


Therefore, longest root of lemon cuttings in the present study was observed in cuttings grown in soil + sawdust + vermicompost. The improved root formation and root growth in this rooting medium could be due to better aeration and drainage and water maintenance capacity of the substrate which are critical for the first phase of root initiation (Eleni et al., 2001 and Noguera et al., 2000). Unlike other growing media, vermicompost contains good amount of 'plant available nutrients' and appears to increase and retain more of them for longer period of time. Therefore, lemon cuttings grown in polybag mixture containing vermicompost had better root growth. The enhanced hydrolytic activity in presence of applied IBA coupled with appropriate rooting medium might be responsible for the increased percentage of rooted cuttings in the present study. The findings of present study are also supported by the fact that IBA and wounding treatments caused accumulation of high level of carbohydrate and low level of nitrogen in cuttings which favored root formation (Snedecor and Cochran, 1968 and Baghel et al., 1993).

In conclusion, the study showed that cuttings, 4000 ppm IBA + wounding was better to induce more rooting parameters in lemon $\mathrm{Cv}$. Pant Lemon-1 while the performance of vermi-compost containing rooting medium (i.e. soil + sawdust + vermi-compost) was observed to be significantly superior over FYM containing rooting medium (i.e. soil + sawdust + FYM) on root growth. The results obtained from this study can be used to develop a protocol for production of quality planting material of lemon through cutting

\section{References}

Abdullah, G.R. and Al-Khateeb, A.A. (2004). Rooting response of lime (Citrus aurantifolia Christm Swingle) cultivar (cv.) Loomi to indole butyric acid
(IBA), rooting media and planting date. Scientific Journal of King Faisal University (Basic and Applied Sciences), 5(2): 253-271

Babu, R. S. H., 2001, Limes and Lemons. In: Chadha, KL ed. Handbook of Horticulture. ICAR, New Delhi, pp.212.

Baghel, B.S., Kirar, D.S., Nema, B.K. and Pandey, S.K. (1993). Effect of mechanical treatments and growth regulators on rooting and growth of seedless lemon (Citrus lemon B.) cuttings. Indian J. Hortic. 50(3): 219223.

Blazich, F.A.: Chemical and formulations used to promote adventitious rooting. In: Davies Constanzi, M., Mela, L. and Garibaladi, A. E.: Preliminary results on multiplication by cuttings of Genistamonosperma. Acta Hort., 226: 327-332 (1988).

Deb, P., Bhowmick, N., Ghosh, S.K. and Suresh, C.P. (2009). Effect of different concentrations of naphthalene acetic acid (NAA) and indole butyric acid (IBA) on success and growth of semi hard wood cutting of lemon (Citrus limon). Environment and Ecology, 27(3): 1130-1131.

Dhua, R.S. and Sen, S.K. (1984). Role of etiolation, auxinic and nonauxinic chemicals on root initiation of air layer of Jack fruit. Indian Journal of Horticulture; 41(1): 116-119.

Eleni, M., Sabri, K. and Dimitra, Z. (2001). Effect of growing media on the production and quality of two rose varieties. Acta Hortic., 548: 79-83.

Ghatnatti, S.A. (1997). Studies on propagation of Duranta plumeri Jacq. by stem cuttings with growth regulators under mist. M.Sc. (Agri.) Thesis, University of Agricultural Sciences, Dharwad.

Kato, (1958). Action and practical application of gibberellins. In plant Physiology. 
UBS publishers distributors Ltd. New Delhi, 418-456.

Kumar, M. and Ponnuswami, V. (2013). Comparison on the effect of vermicompost and inorganic fertilizers on vegetable growth and fruit production of tomato. Open journal of soil science, 5: 53-58.

Kumar, R., Gill, D.S. and Kaushik, R.A. (1995). Effect of indole butyric acid, phydroxy benzoic acid and season on the propagation of lemon cv. Baramasi from cuttings. Haryana Journal of Horticultural Science, 24(1): 13-18.

Kumar, S., Shukla, H.S. and Kumar, S. (2004). Effect of IBA (Indole butyric acid) and PHB (p-hydroxy benzoic acid) on the regeneration of sweet lime (Citrus limetioides Tanaka) through stem cuttings. Progressive Agriculture, 4(1): 54-56.

Murkute, A.A., Sharma, S. and Singh, S.K. (2009). Micropropagation of trifoliate orange (Poncirus trifoliate). Indian Journal of Plant Physiology, 14(2): 190-193

Noguera, P., Abad, M., Noguera, V., Puchades, R.R. and Maquieira, A. (2000). Coconut coir waste, a new and viable ecologically friendly peat substitute. Acta Hort., 517: 279-286.

Panse, V.G. and Sukhatme, P.V. (1985). Statistical method for the agricultural workers $2^{\text {nd }}$ edn. I.C.A.R. New Delhi

Prakash, S. (1984). Effect of plant bio- regulators and chemicals on fruit retention and fruit quality of mango (Mangifera indica L.) cv. Chausa Ph.D thesis submitted to G.B.Pant University of Agriculture and Technology, Pantnagar

Sandhu, A.S and Singh, Z. (1986). Effect of Auxins on the Rooting and Sprouting Behaviour of Stem Cuttings of Sweet Lime (Citrus Limettioides Tanaka). Indian J. of Hort; 43(3/4): 224-226.

Sharma, S., Prakash, A. and Tele, A. (2009). In vitro propagation of citrus rootstocks. Notulae Botanicae, Horti Agrobotanici, Cluj Napoca, 37(1): 8488.

Singh, A.K., Singh, R. (2005). Influence of growth regulating substances on rooting of cuttings of poinsettia cv. Flaming Sphere. Prog. Hort, 37 (1): 85-88.

Singh, K.K., Das, M.M., Samanta, A.K., Kundu, S.S. and Sharma, S.D. (2002). Evaluation of certain feed resources for carbohydrate and protein fractions and in situ digestion characteristics. Indian J. Anim. Sci., 72(9): 794-797.

Snedecor, G.W. and Cochran, W.G. (1968). Statistical Methods, 6th edn, Oxford and IBH Publishing Co., New Delhi.

Verma, S.K., Singh, H., Bhardwaj, P.N. and Arya, R.R. (2005). Propagation of citrus species at Bhowali, Uttaranchal. Prog. Hort., 37(2): 274-279

\section{How to cite this article:}

Babloo Patel, Satya Prakash, Archi Gupta, Shardulya Shukla, Pushkar Dixit, Sonu Katiyar and Kaushlendra Pratap Singh. 2021. Effect of Bio-Regulator Treatment, Wounding and Growing Media on Root Growth of Stem Cutting in Lemon (Citrus limon Burm.). Int.J.Curr.Microbiol.App.Sci. 10(02): 2685-2690. doi: https://doi.org/10.20546/ijcmas.2021.1002.295 